\title{
Children in the Syrian Civil War: the Familial, Educational, and Public Health Impact of Ongoing Violence
}

Abdallah Mohamed Elsafti, MD; Gerlant van Berlaer, MD; Mohammad Al Safadi, MD; Michel Debacker, MD; Ronald Buyl, PhD; Atef Redwan, PhD; Ives Hubloue, PhD

\section{ABSTRACT}

Objective: The Syrian civil war since 2011 has led to one of the most complex humanitarian emergencies in history. The objective of this study was to document the impact of the conflict on the familial, educational, and public health state of Syrian children.

Methods: A cross-sectional observational study was conducted in May 2015. Health care workers visited families with a prospectively designed data sheet in 4 Northern Syrian governorates.

Results: The 1001 children included in this study originated from Aleppo (41\%), Idleb (36\%), Hamah (15\%), and Lattakia (8\%). The children's median age was 6 years (range, $0-15$ years; interquartile range, $3-11$ years), and $61 \%$ were boys. Almost $20 \%$ of the children were internally displaced, and $5 \%$ had deceased or missing parents. Children lacked access to safe drinking water (15\%), appropriate sanitation (23\%), healthy nutrition (16\%), and pediatric health care providers $(64 \%)$. Vaccination was inadequate in $72 \%$. More than half of school-aged children had no access to education. Children in Idleb and Lattakia were at greater risk of having unmet public health needs. Younger children were at greater risk of having an incomplete vaccination state.

Conclusions: After 4 years of civil war in Syria, children have lost parents, live in substandard life quality circumstances, and are at risk for outbreaks because of worsening vaccination states and insufficient availability of health care providers. (Disaster Med Public Health Preparedness. 2016;10:874-882)

Key Words: Syria, children, public health, education, civil war

$\mathrm{T}$ he civil war that started on March 15, 2011, in Syria, a country with formerly 22 million inhabitants, was responsible for over 191,369 certified violent deaths in 5 years' time, including at least 16,970 children. $^{1-3}$ The high proportion of fatalities among children is reported to be due to bombing attacks, shrapnel injuries, and gunshot wounds. ${ }^{4}$ The real death toll is estimated at 300,000 people, including over 100,000 civilians, of whom $23 \%$ are children. ${ }^{1-5}$ In addition, an estimated 300,000 Syrians have been injured, of whom 17\% were children, and over 100,000 adults are missing. In approximately 144,000 families (corresponding to about 1 million individuals), there is no wage-earner left. ${ }^{6}$ By the end of 2015, 7 million Syrians had fled their homes to internally displaced person (IDP) camps inside Syria and another 5 million to overcrowded refugee camps (RCs) in neighboring countries such as Turkey, Lebanon, and Jordan. Most people were relocated more than once, and more than 1 million undertook a dangerous journey toward Europe $^{5,6}$ Considering deaths, injuries, detentions, missing persons, refugees, and displaced persons, the crisis has severely affected almost 14 million Syrians. ${ }^{2}$
Before 2011, Syria seemed to be on track to fulfilling the health Millennium Development Goals. ${ }^{7,8}$ Most children were followed by "Patient Centered Medical Homes" staffed with primary and specific health care providers delivering integrated mother and child care. ${ }^{9,10}$ However, 5 years of war has demolished most specific health care centers, and the remaining centers are not functional. ${ }^{1,8}$ This severely complex and dynamic humanitarian emergency situation is an immense challenge for relief efforts of national and international emergency medical teams, as an estimated 4 million people are in areas difficult to access for aid and relief organizations. ${ }^{11}$ According to the World Health Organization (WHO), the Syrian crisis is the worst humanitarian crisis yet in the 21 st century. ${ }^{2,5,8,12}$

This is especially true for children as a vulnerable population, as their social, educational, physical, and mental health states are all affected. ${ }^{12,13}$ Half of the displaced persons are minors, who are at risk for illness, malnourishment, abuse, or exploitation. ${ }^{6}$ Either on the run, or still in their demolished villages, millions of them have been forced to quit 
school. According to reports by Médecins Sans Frontières, half of all children are missing out on vaccinations, and 1 in 4 children is at risk of developing a mental health disorder. ${ }^{5}$ Children residing in IDP camps or RCs are at higher risk for malnutrition, because of compromised access to nutritious foods. ${ }^{12,14}$ In the last 5 years, more than 300,000 Syrian children have been born as IDPs or refugees. ${ }^{12}$ Most of the Syrian economic, social, educational, and health care infrastructures have been destroyed. ${ }^{1}$ Syrian children-the nation's hope for a better future-are among the most vulnerable victims of the war: they have lost loved ones, suffered injuries, missed years of education, and witnessed violence and brutality. ${ }^{13}$ Warring parties forcibly recruit children as young as 7 to serve as fighters, human shields, or in support roles. ${ }^{3,12}$

The efforts of relief organizations focus mainly on war injuries and preventive measures but pay too little attention to more vulnerable populations in the community. There is an urgent need for scientific research to document this complex humanitarian emergency. ${ }^{8}$ Public health literature on the Syrian crisis is scarce and only a limited number of epidemiological studies have been published. ${ }^{4,5,13-16}$

This study aimed to document the familial, educational, and public health state of Syrian children after 4 years of conflict and to estimate the need for relief efforts to provide minimum standards of care to Syrian children. The study hypothesis was that due to the crisis, the current familial, educational, and health state of Syrian children is lowered to substandard.

\section{METHODS}

\section{Study Design}

A cross-sectional descriptive sample analysis was performed on prospectively designed data sheets collected by Qatar Red Crescent (QRC) on May 21 and 22, 2015. The study protocol was approved by the Ethical Committee of the Universitair Ziekenhuis Brussel, Belgium (approval number B.U.N. 143201524794). A data sharing and research collaboration agreement was signed between $\mathrm{QRC}$ and the researchers. All participants gave oral informed consent before taking part.

\section{Setting}

QRC has been present in 7 Syrian governorates (Aleppo, Idleb, Hamah, Lattakia, Al-Raqqah, Deir-ez-Zor, and Al-Hasakeh) since 2011 with 173 health care professionals, largely experienced in independent monitoring of polio vaccination campaigns and sampled cluster household surveys. Before the start of the study, a data sheet (available in English and Arabic) was designed that focused on demographic, social, educational, and public health data of children. A group of 30 data collectors, already active in Northern Syria, was selected by QRC/WHO experts and received a training course provided by the research group of
TABLE

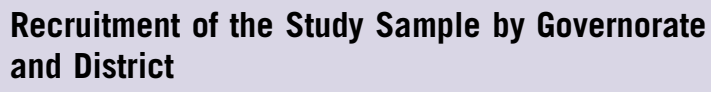

\begin{tabular}{llccc}
\multirow{2}{*}{ Governorate } & District & $\begin{array}{c}\text { No. of Data } \\
\text { Collectors }\end{array}$ & $\begin{array}{c}\text { No. of } \\
\text { Working } \\
\text { Days }\end{array}$ & $\begin{array}{c}\text { No. of Filled Out } \\
\text { Questionnaires }\end{array}$ \\
Aleppo & Aleppo City & 4 & 2 & 160 \\
& Zerbh & 2 & 2 & 80 \\
& Atareb & 2 & 2 & 80 \\
\multirow{4}{*}{ Idleb } & Deir Hafer & 2 & 2 & 80 \\
& Idleb City & 2 & 2 & 80 \\
& Ariha & 2 & 2 & 80 \\
& Harem & 2 & 2 & 80 \\
\multirow{4}{*}{ Hamah } & Jesr Shoughour & 2 & 2 & 80 \\
& Maara & 2 & 2 & 80 \\
& Hama City & 2 & 2 & 80 \\
& Sqelbieh & 1 & 2 & 40 \\
\multirow{4}{*}{ Lattakia } & Salamieh & 1 & 2 & 40 \\
\multirow{4}{*}{ Total } & Mhardeh & 1 & 2 & 40 \\
& Lattakia City & 1 & 2 & 40 \\
& Kensabba & 1 & 2 & 40 \\
& & $\mathbf{2 7}$ & $\mathbf{2}$ & 1080 \\
\hline
\end{tabular}

this study, explaining the concept, methodology, process, and forms of the study, as well as how to debrief victims and how to deal with difficult humanitarian issues. The data collectors then visited families home by home in households and IDP camps from 4 Northern Syrian governorates. The data sheets were reassembled and sent to the QRC office in Gaziantep, Turkey.

\section{Participants and Sample Size}

In the context of the ninth polio vaccination campaigns by QRC, a cluster sample of 1080 Syrian children was selected randomly by using QRC population estimates of governorate districts, with systematic random selection of households within clusters, using the QRC list of registered accessible homes, IDP camps, and health centers in the 4 Northern Syria governorates: Aleppo, Idleb, Hamah, and Lattakia (Table 1). ${ }^{17}$ Every child younger than 15 years old was eligible for inclusion. If the child was too young to answer some of the questions, these were answered by the guardian of the child. Oral informed consent from the child and a guardian was obtained before the interview.

\section{Variables}

By means of a prospectively designed data sheet with check boxes and free text fields, the data collectors registered the child's age, gender, habitat details including displacement, family, and guardian state. On the basis of answers provided by the child or the child's legal guardian to their targeted questions, inspection of the child's residence and environment, and clinical examination of the child, the data 
collectors assessed water and sanitation information, access to (healthy) food, education state, availability of specific health care facilities, and the child's vaccination and nutrition state. An example of the data collection sheet can be found as an Online Data Supplement.

\section{Data Sources and Measurement}

All data were anonymized according to the Helsinki Declaration. The collected data sheets were scanned and analyzed by qualified auditors to remove incomplete forms. The data were compiled into an interface especially designed for this study by the QRC data entry team, which included a data entry manager, an auditor, and analysts. Finally, the dataset was sent to the researchers and once more revised to eliminate errors as much as possible.

\section{Bias}

Although this study was thoroughly prepared in advance, with prospectively designed data sheets and well-trained and qualified data collectors, circumstances in the field were complex. The forms were filled out by different data collectors, possibly introducing sampling bias. A possible answer bias could be introduced by families fearing repercussions by authorities, when declaring or expressing suffering or discomfort of their children.

\section{Statistical Methods}

Children with missing or unreadable data were excluded. Descriptive statistics for discrete outcome variables were presented as frequencies and proportions ( $\mathrm{n}$; \%), and for quantitative variables (age, number of children) as median, range, and interquartile range (IQR). The analyses were broken down for age $(<5$ and $\geq 5$ years old $)$ and region (4 governorates).

Pearson's chi-square analysis was performed to identify factors associated with the health problems by using water access, proper sanitation, healthy food, accessible health care, and vaccination state as outcome variables and by using origin (governorate), age category ( $<5$ and $\geq 5$ years old), and gender as predictors. Analyses were carried out by using SPSS v23.0 (IBM Corp, Armonk, NY). All tests were performed by using an $\alpha$-level of 0.05 .

\section{RESULTS}

\section{Participants}

After we excluded forms with missing data, a total of 1001 children were included in the study. Depending on the examined item, the number of appropriate participants differed from the total included population in the following cases: when looking at vaccination state, infants under the age of the first vaccination were omitted; and when looking at access to education, only school-aged children ( $\geq 6$ years old) were considered.

\section{Descriptive Data}

Of all included children, more than half were male $(\mathrm{n}=611 ; 61 \%)$; females accounted for 39\% $(\mathrm{n}=389)$. The children's median age was 6 years (range, $0-15$ years; IQR, 3-11 years). Children younger than 5 accounted for $40 \%(n=398)$, children older than 5 for $59 \%(n=596)$. The exact age was missing for 7 children. The median number of siblings was 3 (range, 1-9; IQR, 2-5) for the whole sample, but was less in Hamah (median: 2; IQR, 1-4) than in Lattakia (median: 3; IQR, 2-4), Aleppo (median: 3; IQR, 2-5), and Idleb (median: 4; IQR, 3-5). Most of the children included were recruited in Aleppo governorate $(\mathrm{n}=413 ; 41 \%) ; 359$ were recruited in Idleb (36\%), 147 in Hamah (15\%), and 82 in Lattakia (8\%) as shown in Figure 1.

\section{Outcome Data}

An overview of all outcome data and encountered problems is given in Table 2 and Figure 2.

\section{Main Results}

Almost 20\% $(n=196)$ of all children were displaced to IDP camps. Relatively more children were displaced in Lattakia (46\%) and Hamah (33\%) than in Aleppo (15\%) and Idleb (14\%). A total of 86 children (9\%) had lost their father: 45 had fathers who were deceased (5\%) and 41 had fathers who were missing (4\%). Forty-six children (5\%) had lost their mother: 19 had mothers who were deceased (2\%) and 27 had mothers who were missing (3\%).

In 828 families (83\%), the father was the principal guardian. This role of family guardian was taken over in 57 cases by an uncle $(6 \%)$, in 32 families by the mother $(3 \%)$, in 30 households by an older brother (3\%), in 27 families by grandparents $(3 \%)$, and in 24 cases by others $(2 \%)$ external to the original family. In 3 families the actual situation was unclear. Overall, in 173 families (17\%), the father was not the principal guardian.

Almost 9\% ( $n=80 / 935)$ of children could not access safe drinking water. For 66 children (7\%), safe access was unknown. Safe drinking water access was most lacking in Lattakia (21\%) and Idleb (40\%).

Appropriate sanitation was inaccessible for $15 \%$ of children $(\mathrm{n}=135 / 910)$. For 91 children (9\%), access was unclear. Sanitation facilities were most lacking in Lattakia (40\%) and Idleb (20\%).

Access to regular nutrition was available for 845 children (84\%). A total of 147 children (15\%) could not access regular feeding at the time of the study; for 9 children (1\%) this was unknown. This problem was most prominent in Lattakia (32\%) and Idleb (22\%). 


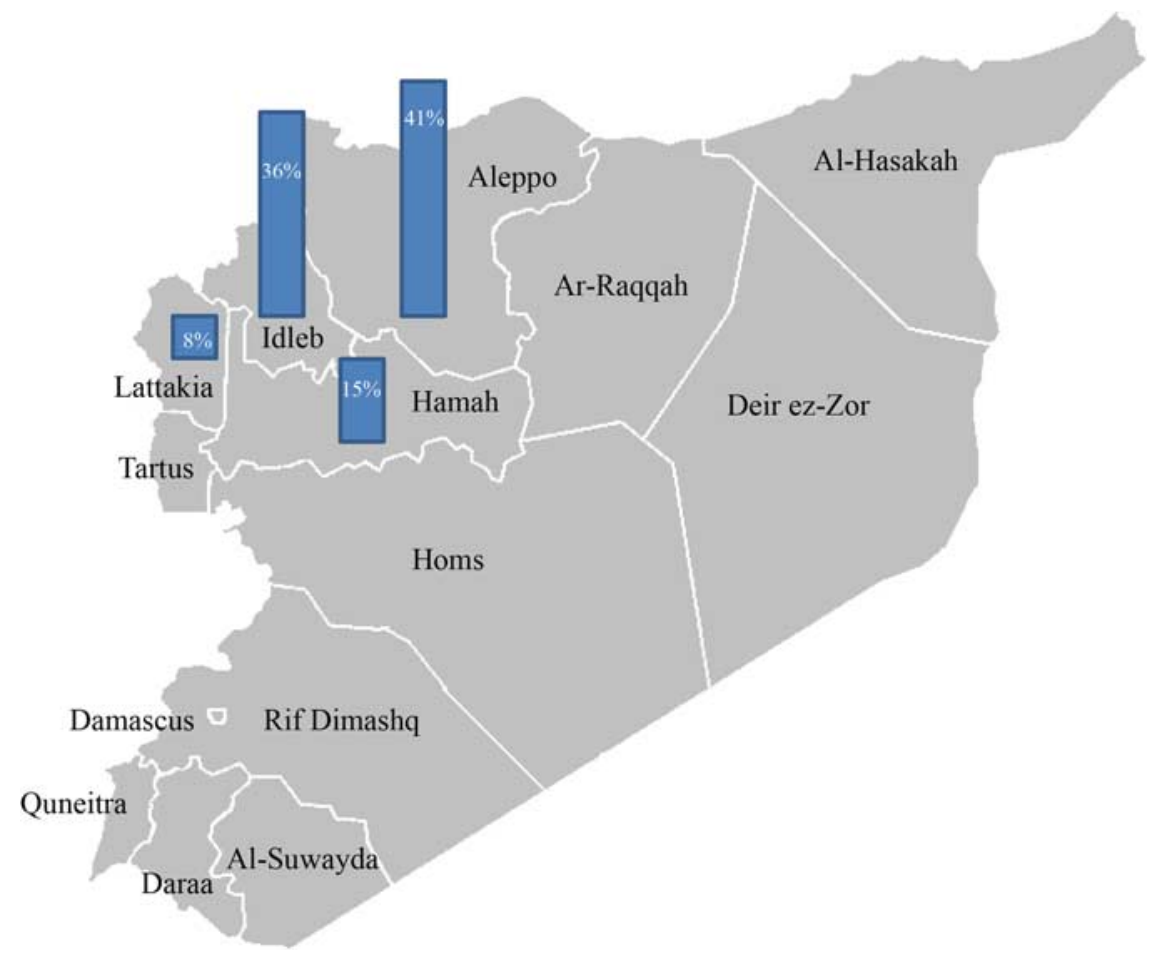

Of all children, 726 (73\%) received safe and healthy food, 205 children (21\%) did not eat healthy, and for 70 children (7\%) this was unclear. This problem was most expressed in Idleb, where $44 \%$ of children did not have access to safe and healthy food.

For 133 children who were breastfed, only 78 (59\%) received their mother's milk, whereas 55 (41\%) could not be nourished by their own mother at the time of the study. For 104 children receiving artificial feeding, 64 (62\%) could not access the best possible artificial feeding at the time of the study.

Among all children with a registered nutrition state ( $\mathrm{n}=846 ; 85 \%$ ), almost $32 \%$ suffered from clinical signs of malnutrition. This problem was more apparent in Idleb (48\% malnutrition), in Aleppo (28\%), and in Hamah (19\%), but was less present in Lattakia (4\%).

Half of all 882 children of school age had no access to education at the time of the study $(n=450 ; 51 \%)$. This was an important problem in all governorates, but was most expressed in Idleb (71\% dropouts) and Lattakia (66\% dropouts). The educational provider was unknown in most cases ( $\mathrm{n}=840 ; 84 \%$ ). If the educational provider was known, the available education was most frequently not organized by the government in Northern Syria $(\mathrm{n}=44 ; 28 \%)$ but by other providers $(\mathrm{n}=114 ; 72 \%)$.
Most children ( $\mathrm{n}=632 ; 64 \%)$ could not access specific mother and child health care providers at the time of the study. This problem affected all 82 children $(100 \%)$ in Lattakia, but was prominent as well in Idleb (71\%), Aleppo (57\%), and Hamah (48\%). When present, health care was mostly provided by humanitarian agencies $(n=263 ; 82 \%)$, governmental health facilities $(\mathrm{n}=28 ; 9 \%)$, or private initiatives $(\mathrm{n}=28 ; 9 \%)$.

The children's vaccination state was not available for $34 \%$ of the respondents $(n=342)$. Of the children with a known vaccination state $(n=659 ; 66 \%)$, the state was not up-to-date in 214 cases $(43 \%)$, of a comparable proportion in all governorates, and incomplete in 132 cases (17\%). An incomplete vaccination state was most present in Aleppo (32\%). Of all children having access to vaccination $(\mathrm{n}=985), 297$ children (30\%) had missed at least one vaccine. This problem was most important in Aleppo, where almost half of the children had missed vaccines $(45 \%)$. The most frequently missed vaccines were those against measles $(\mathrm{n}=126 ; 12 \%)$, hepatitis $\mathrm{B}$ $(\mathrm{n}=99 ; 10 \%)$, tetanus/pertussis/diphtheria $(\mathrm{n}=96 ; 10 \%)$, polio $(\mathrm{n}=78 ; 8 \%)$, and tuberculosis $(\mathrm{n}=77 ; 8 \%)$.

\section{Other Analyses}

The statistical analysis presented in Table 3 indicates that the risk for children to have unmet needs depended mainly on 


\section{TABLE 2}

\begin{tabular}{|c|c|c|c|c|c|}
\hline \multicolumn{6}{|c|}{ Outcome Data for the Syrian Children Surveyed ${ }^{a}$} \\
\hline & Aleppo & Idleb & Hamah & Lattakia & Total \\
\hline \multirow[t]{2}{*}{ Participants, no. (\%) } & 413 & 360 & 147 & 82 & 1001 \\
\hline & $(41.2)$ & (35.9) & $(14.7)$ & $(8.2)$ & (100) \\
\hline \multirow[t]{2}{*}{ Siblings, median no. (IQR) } & 3 & 4 & 2 & 3 & 3 \\
\hline & $(2-5)$ & $(3-5)$ & $(1-4)$ & $(2-4)$ & $(2-5)$ \\
\hline \multirow[t]{2}{*}{ Displaced, no. (\%) } & 61 & 48 & 49 & 38 & 196 \\
\hline & $(14.9)$ & $(13.4)$ & (33.3) & $(46.3)$ & (19.6) \\
\hline \multirow[t]{2}{*}{ Do not own house, no. (\%) } & 29 & 23 & 0 & 0 & 52 \\
\hline & $(7.7)$ & (6.8) & (0) & (0) & (6.0) \\
\hline \multirow[t]{2}{*}{ No safe water, no. (\%) } & 25 & 37 & 1 & 17 & 80 \\
\hline & $(6.9)$ & $(10.4)$ & $(0.8)$ & $(20.7)$ & (8.6) \\
\hline \multirow[t]{2}{*}{ No sanitation, no. (\%) } & 29 & 70 & 3 & 33 & 135 \\
\hline & $(8.0)$ & (19.8) & $(2.7)$ & $(40.2)$ & (14.8) \\
\hline \multirow[t]{2}{*}{ No food access, no. (\%) } & 42 & 78 & 1 & 26 & 147 \\
\hline & $(10.2)$ & $(21.7)$ & $(0.7)$ & $(31.7)$ & $(14.8)$ \\
\hline \multirow[t]{2}{*}{ No healthy food, no. (\%) } & 50 & 154 & 0 & 1 & 205 \\
\hline & $(12.9)$ & $(43.9)$ & (0) & (1.3) & (22.0) \\
\hline \multirow[t]{2}{*}{ No education, no. (\%) } & 137 & 210 & 58 & 46 & 451 \\
\hline & $(39.1)$ & $(70.7)$ & $(54.7)$ & $(65.7)$ & $(54.8)$ \\
\hline \multirow{2}{*}{$\begin{array}{l}\text { No specific health care, } \\
\text { no. (\%) }\end{array}$} & 233 & 249 & 68 & 82 & 632 \\
\hline & $(56.8)$ & $(70.6)$ & $(47.9)$ & $(100)$ & $(64.0)$ \\
\hline \multirow{2}{*}{$\begin{array}{l}\text { Vaccination incomplete, } \\
\text { no. (\%) }\end{array}$} & 98 & 20 & 9 & 5 & 132 \\
\hline & $(31.7)$ & (6.3) & (8.3) & $(8.6)$ & $(16.7)$ \\
\hline \multirow{2}{*}{$\begin{array}{l}\text { Vaccination not up-to-date, } \\
\text { no. (\%) }\end{array}$} & 107 & 64 & 31 & 12 & 214 \\
\hline & $(49.1)$ & $(33.0)$ & $(53.5)$ & $(50.0)$ & (43.3) \\
\hline \multirow[t]{2}{*}{ Clinical malnutrition, no. (\%) } & 96 & 149 & 21 & 3 & 269 \\
\hline & (27.9) & (47.9) & (19.1) & $(3.7)$ & (31.8) \\
\hline
\end{tabular}

${ }^{a}$ Abbreviation: IQR, interquartile range.

the governorate in which they resided. The most affected governorates were Idleb and Lattakia for water, sanitation, education, and health care and Aleppo for missing vaccines. These problems were not linked to gender or age, except for vaccination state: the smaller the children, the more at risk they were for having an incomplete vaccination state.

\section{DISCUSSION \\ Key Results}

Almost 20\% of the children were internally displaced at the time of the study. Lattakia harbored the highest proportion of displaced children $(46 \%)$, probably because this governorate - far from the front lines at that time-was regarded as a secure place to which to escape. ${ }^{6}$ In the meantime, however, Lattakia entered the conflict through hosted external armed forces, forcing more families to move out. It should also be remembered that Syria was the host for many Iraqi refugees who fled their country before 2011, which increased the vulnerable and pediatric populations in IDP camps. ${ }^{18}$

An already vulnerable population, weakened even more by displacement, loss of family guardians, and unavailability of school, is at higher risk of being physically or sexually abused, exploited as a cheap working force, or even recruited as childsoldiers. As a consequence, many children have fled their homes and families to seek a safer and better future outside Syria. The United Nations Children's Emergency Fund (UNICEF) reported that already over 15,000 unaccompanied children have crossed the Syrian borders. ${ }^{12}$ An even higher number arrived unaccompanied in Europe over the last 2 years. ${ }^{19}$

Almost $14 \%$ of all included children had lost one or both of their parents. This finding is consistent with the findings of Sirin et al indicating that $74 \%$ of Syrian refugee children in Turkey had experienced the death of a loved one and UNICEF reports stating that up to 1 million children have lost parents in the Syrian conflict. ${ }^{12,20}$

In Syrian culture, the father acts as the principal guardian of the family. In our study, this cultural standard was met in only $83 \%$ of the families, whereas in $17 \%$, mothers, uncles, grandparents, older brothers, or even others external to the family had taken over that task. This reflects the major dependence of children on predominantly male family members, who are unfortunately often involved in war activities or might have disappeared. The mental effects of this crisis on children will entail many consequences in the coming decades. ${ }^{12,13,21,22}$

For children, but even more for the future of a country, education is mandatory. Before $2011,97 \%$ of primary schoolaged children were educated. ${ }^{12}$ In 2014, Doocy and colleagues found that already one-third had dropped out of school. ${ }^{6}$ This study emphasizes the important loss of education capacity for the remaining Syrian population and the rapid worsening with time: more than half of the children were not enrolled in school at the time of the study. In Idleb, this even increased to $71 \%$, possibly because this governorate suffered more from loss of community activities, overcrowding of IDP camps, and massive destruction of public constructions, such as schools. ${ }^{12}$ Humanitarian relief efforts and private initiatives try to mitigate this problem by providing education to about three-quarters of the school-going children included in this study, but this is far from sufficient, as stated in recent United Nations Office for the Coordination of Humanitarian Affairs and UNICEF reports. ${ }^{2,12}$

One of the major concerns in complex humanitarian emergencies is the population's public health. During this civil war, half of the essential infrastructures needed to maintain a population's health are destroyed, partially functioning, or inaccessible. ${ }^{5}$ Moreover, an estimated $70 \%$ of all health care providers have fled the country, as hospitals, patients, and medical staff are systematically and deliberately targeted by militia. ${ }^{8,15}$

Before the crisis, access to safe drinking water was available for $93 \%$ of the urban and $86 \%$ of the rural population. ${ }^{8}$ In this study, overall $8 \%$ had no access to safe drinking water, but there were strong regional differences: in Lattakia (suffering from overcrowded IDP camps) this proportion reached $21 \%$, and in Idleb (suffering most from destroyed infrastructure) it was $10 \%$. 
Proportion of Problems and Unmet Needs Encountered by Children (\%), by Syrian Governorate.

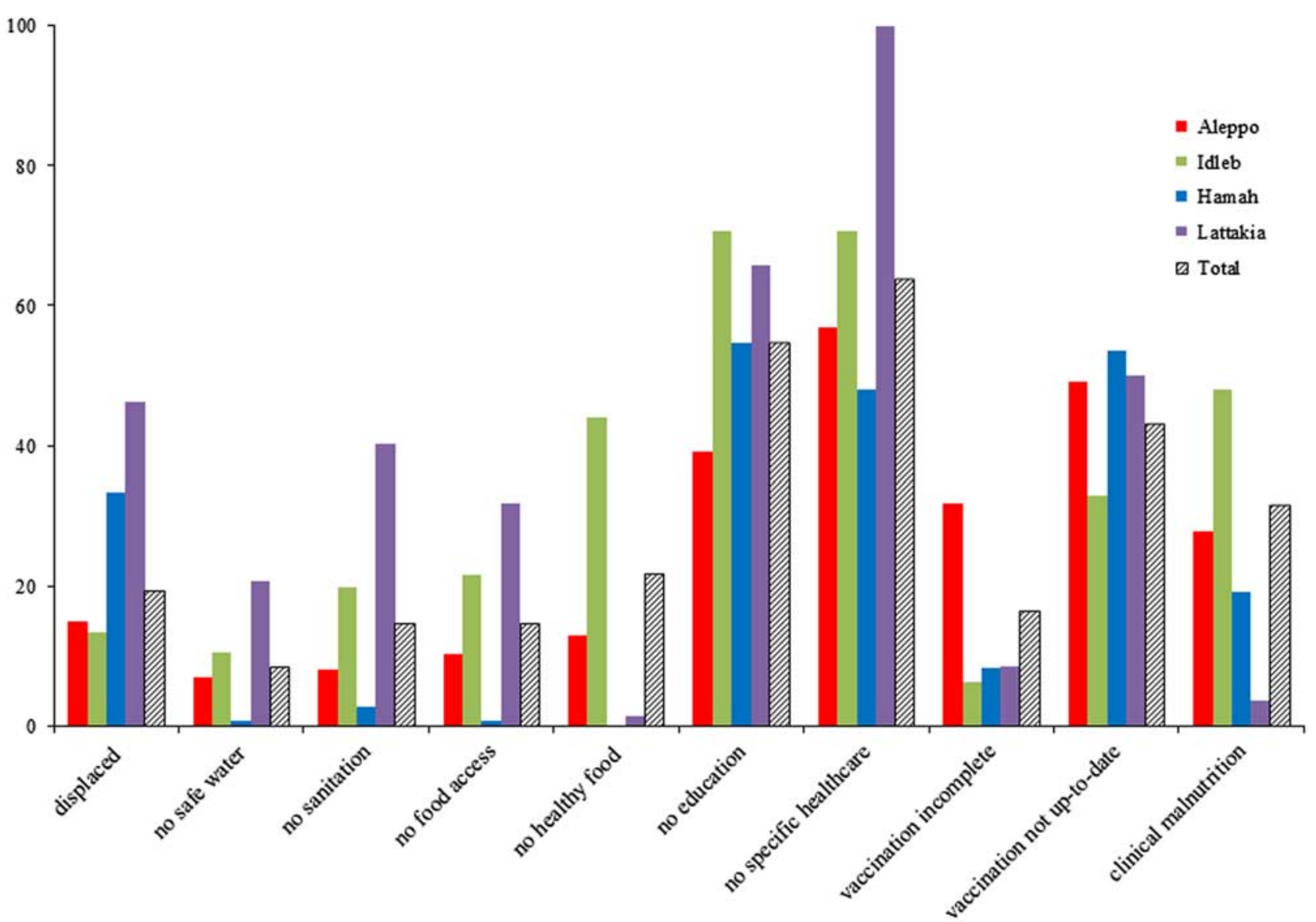

Yet, the result in this study was less demonstrative than the one-third reported by Doocy and colleagues in 2014. ${ }^{6}$ Proper sanitation was unavailable for $14 \%$ of children, again with worse outcomes in Lattakia (40\%) and Idleb (20\%), numbers consistent with UNICEF reports in 2015. ${ }^{12}$

One in 7 children was not fed on a regular basis, and for 1 in 5 of those who were, the food was neither safe nor healthy. This is similar to the $12 \%$ of internally displaced families provided with unsafe food reported by Doocy and colleagues. ${ }^{6}$ They also stated that up to $90 \%$ of people inside Syria face obstacles accessing food. This study indicates that close to $80 \%$ of displaced families reported being dependent on a combination of humanitarian food aid and purchased food.

Almost 32\% of children showed clinical signs of malnutrition at the time of the study, consistent with earlier UNICEF reports, but worse than figures reported from RCs in Jordan. ${ }^{12,14}$ The principal indicator of the nutritional state of children aged 6-59 months in humanitarian emergencies is the Global Acute Malnutrition (GAM) classification. ${ }^{14,23}$ Prior to the civil war, Syrian children scored poorly, with a
GAM prevalence of $10 \%$, stunting in $23 \%$, underweight in $10 \%$, and with markedly prevalent micronutrient deficiencies (29\% anemia, 9\% vitamin A deficiency, and 13\% iodine deficiency). ${ }^{8,23,24}$ These conditions emerge even more in displaced people, with more than 10\% GAM and about 2-5\% severe malnutrition among children. ${ }^{8}$ With actual clinical malnutrition rates in this study of $32 \%$ of the children (even up to $48 \%$ in Idleb), these results call for urgent, directed interventions to prevent adverse evolution. A possible beneficial policy would be for humanitarian programs to fortify supplied flour with micronutrients, as this has shown improvement in child and maternal micronutrient states within Syrian refugees in Jordan. ${ }^{14}$

Breastfeeding, which is essential for infants' growth and physical and mental health, is dependent on the social and nutritional well-being of the mother. ${ }^{13,25}$ Already before the crisis, according to Al-Akour and colleagues, infant feeding practices were poor in Syria, with low early breastfeeding initiation after birth (32\%) and low rates of exclusive breastfeeding to 6 months $(29 \%){ }^{25}$ This study found comparable low results regarding breastfeeding, but the 
TABLE 3

\begin{tabular}{|c|c|c|c|c|c|c|c|}
\hline \multirow{2}{*}{$\begin{array}{l}\text { Predictive } \\
\text { Unmet need } \\
\text { Safe water }\end{array}$} & \multicolumn{5}{|c|}{ Predictors (\%) } & \multirow{2}{*}{$\begin{array}{c}\text { Significant } \\
+\end{array}$} & \multirow{2}{*}{$\begin{array}{l}\boldsymbol{P} \text { Value } \\
<0.0001\end{array}$} \\
\hline & Governorate & $\begin{array}{c}\text { Aleppo } \\
6.9\end{array}$ & $\begin{array}{l}\text { Idleb } \\
10.4\end{array}$ & $\begin{array}{l}\text { Hamah } \\
0.7\end{array}$ & $\begin{array}{c}\text { Lattakia } \\
20.7\end{array}$ & & \\
\hline & Gender & \multicolumn{2}{|c|}{$\begin{array}{l}\text { Female } \\
9.6\end{array}$} & \multicolumn{2}{|c|}{$\begin{array}{c}\text { Male } \\
7.9\end{array}$} & & 0.359 \\
\hline & Age & \multicolumn{2}{|c|}{$\begin{array}{c}<5 \text { years } \\
6.5\end{array}$} & \multicolumn{2}{|c|}{$\begin{array}{c}\geq 5 \text { years } \\
9.8\end{array}$} & & 0.075 \\
\hline \multirow[t]{3}{*}{ Sanitation } & Governorate & $\begin{array}{c}\text { Aleppo } \\
8.0\end{array}$ & $\begin{array}{l}\text { Idleb } \\
19.9\end{array}$ & $\begin{array}{c}\text { Hamah } \\
2.7\end{array}$ & $\begin{array}{c}\text { Lattakia } \\
40.2\end{array}$ & + & $<0.0001$ \\
\hline & Gender & \multicolumn{2}{|c|}{$\begin{array}{l}\text { Female } \\
17.5\end{array}$} & \multicolumn{2}{|c|}{$\begin{array}{l}\text { Male } \\
13.2\end{array}$} & & 0.071 \\
\hline & Age & \multicolumn{2}{|c|}{$\begin{array}{c}<5 \text { years } \\
11.9\end{array}$} & \multicolumn{2}{|c|}{$\begin{array}{c}\geq 5 \text { years } \\
16.5\end{array}$} & & 0.058 \\
\hline \multirow[t]{3}{*}{ Specific health care } & Governorate & $\begin{array}{c}\text { Aleppo } \\
56.8\end{array}$ & $\begin{array}{l}\text { Idleb } \\
70.5\end{array}$ & $\begin{array}{l}\text { Hamah } \\
47.9\end{array}$ & $\begin{array}{c}\text { Lattakia } \\
100.0\end{array}$ & + & $<0.0001$ \\
\hline & Gender & \multicolumn{2}{|c|}{$\begin{array}{l}\text { Female } \\
62.0\end{array}$} & \multicolumn{2}{|c|}{$\begin{array}{l}\text { Male } \\
65.2\end{array}$} & & 0.301 \\
\hline & Age & \multicolumn{2}{|c|}{$\begin{array}{c}<5 \text { years } \\
60.7\end{array}$} & \multicolumn{2}{|c|}{$\begin{array}{l}\geq 5 \text { years } \\
66.3\end{array}$} & & 0.074 \\
\hline \multirow[t]{3}{*}{ Vaccination state } & Governorate & $\begin{array}{c}\text { Aleppo } \\
49.1\end{array}$ & $\begin{array}{l}\text { Idleb } \\
33.0\end{array}$ & $\begin{array}{l}\text { Hamah } \\
53.4\end{array}$ & $\begin{array}{c}\text { Lattakia } \\
50.0\end{array}$ & + & 0.003 \\
\hline & Gender & \multicolumn{2}{|c|}{ Female } & \multicolumn{2}{|c|}{$\begin{array}{l}\text { Male } \\
43.3\end{array}$} & & 0.976 \\
\hline & Age & \multicolumn{2}{|c|}{$\begin{array}{c}<5 \text { years } \\
38.5\end{array}$} & \multicolumn{2}{|c|}{$\begin{array}{c}\geq 5 \text { years } \\
48.3\end{array}$} & + & 0.029 \\
\hline \multirow[t]{3}{*}{ Vaccines up-to-date } & Governorate & $\begin{array}{c}\text { Aleppo } \\
45.2\end{array}$ & $\begin{array}{l}\text { Idleb } \\
17.1\end{array}$ & $\begin{array}{c}\text { Hamah } \\
23.8\end{array}$ & $\begin{array}{c}\text { Lattakia } \\
24.4\end{array}$ & + & $<0.0001$ \\
\hline & Gender & \multicolumn{2}{|c|}{$\begin{array}{l}\text { Female } \\
31.3\end{array}$} & \multicolumn{2}{|c|}{$\begin{array}{l}\text { Male } \\
29.5\end{array}$} & & 0.542 \\
\hline & Age & \multicolumn{2}{|c|}{$\begin{array}{c}<5 \text { years } \\
36.8\end{array}$} & \multicolumn{2}{|c|}{$\begin{array}{l}\geq 5 \text { years } \\
26.0\end{array}$} & + & $<0.0001$ \\
\hline \multirow[t]{3}{*}{ Education } & Governorate & $\begin{array}{c}\text { Aleppo } \\
37.8\end{array}$ & $\begin{array}{l}\text { Idleb } \\
66.9\end{array}$ & $\begin{array}{l}\text { Hamah } \\
40.5\end{array}$ & $\begin{array}{c}\text { Lattakia } \\
41.1\end{array}$ & + & $<0.0001$ \\
\hline & Gender & \multicolumn{2}{|c|}{$\begin{array}{l}\text { Female } \\
47.6\end{array}$} & \multicolumn{2}{|c|}{$\begin{array}{l}\text { Male } \\
50.8\end{array}$} & & 0.490 \\
\hline & Age & \multicolumn{2}{|c|}{$<5$ years } & \multicolumn{2}{|c|}{$\begin{array}{c}\geq 5 \text { years } \\
49.6\end{array}$} & & - \\
\hline
\end{tabular}

availability of substitute feeding for infants seemed even more affected: up to $62 \%$ of infants did not receive the best possible artificial feeding at the time of the study.

For most children (64\%), specific health care was not accessible at the time of the study, consistent with reports stating that all primary health care services for maternal and child health in Northern Syria have been disrupted since 2013. ${ }^{8}$ A QRC analysis in 2014 reported a dramatic reduction in pediatric health care facilities since the beginning of the Syrian crisis: infant bed rates decreased from 6 to $0.8 / 10,000$ in Aleppo and from 3.4 to 1.9 in Idleb. ${ }^{7,26}$ The Lattakia governorate did not dispose of pediatric beds before the crisis.

When present, pediatric health care was almost always provided by humanitarian agencies $(83 \%)$, reflecting the dependency on external medical teams and temporary relief health centers. Before 2011, the public sector provided more than $80 \%$ of hospital beds, and there was a limit on fees for private providers. ${ }^{7,8}$ In this study, only $9 \%$ of the provided health care was organized by the government and $9 \%$ by local private initiatives. This creates an extra burden to the country, demanding international efforts to protect and improve the remaining Syrian health care system and infrastructure for the uncertain future.

The immunization state of children is another prominent health care parameter in complex humanitarian emergencies. UNICEF reported a decrease in Syrian children's immunization rates from over $90 \%$ before the conflict to $68 \%$ in $2015 .^{12}$ Almost half of the surveyed children (43\%) did not have an up-to-date vaccination state, an issue equally present in all 4 governorates, and concordant with the numbers in the 2015 World Report on Syria by Devi. ${ }^{5}$ Even from children having access to vaccination facilities, the state was 
incomplete in $17 \%$, and $30 \%$ missed at least one vaccination. Measles, one of the top 5 killers in IDP children, was covered in about $80 \%$ of children according to a United Nations Development Program report in 2012.,15,27 In this study, measles was the most frequently missing vaccine, probably due to the interruption of measles vaccination programs after a serious incident reported in 2014, when 75 children were given the measles vaccine accidentally mixed with atracurium instead of the normal diluent and 15 died. ${ }^{28}$ As a consequence, over 7000 measles cases were recently identified in Northern Syria. ${ }^{15}$ However, the surveyed children in this study are also at increased risk for hepatitis B, tetanus, pertussis, diphtheria, polio, and tuberculosis. After 15 years of polio eradication, at least 37 new flaccid paralysis cases were officially identified in Northern Syria. ${ }^{15,29}$

These findings raise serious concerns about the protection of Syrian children against preventable communicable diseases and epidemics, not only inside Syria, but also in the surrounding and European countries, where millions are in search for the official status of refugee today. This threat was already documented by epidemics in neighboring countries and by a first measles outbreak in 2016 in a RC in Northern France. ${ }^{30}$

\section{Limitations and Strengths}

This study had several limitations. The dynamic nature of the conflict and security vigilance forced the research and survey team to alter the aimed composition of the study population. The sampling was done in 4 governorates only (as other regions are unsafe with terrorist activity) with an inclusion disproportion favoring Aleppo and Idleb, with more crowded and poor districts, versus the limited presence of IDPs in Lattakia and Hamah.

The strengths of the study are the considerable number of inclusions, the prospectively designed data registry records, and the extended information on public services and health care in a disaster region.

\section{CONCLUSIONS \\ Interpretation}

After 4 years of civil war in Syria, many children have lost their parents, are being displaced, and live in substandard life quality circumstances. Most children miss education, undermining their own future and that of the country. Limited access to water, to sanitation, and to regular and healthy food, together with increasing malnutrition rates, worsening of the immunization state, and worsening accessibility to specific health care facilities add up to factors that put Syrian children at risk for increased morbidity and mortality.

As physicians, in accordance with international humanitarian laws, we recommend an immediate stop to the attacks on schools, hospitals, and other critical civilian infrastructure. Urgent coordinated and global action is needed to deal with this complex humanitarian emergency and to prevent the worsening of the social, educational, and public health threats for children in Syria.

\section{Generalizability}

The findings of this study are specific to the Northern Syrian region, particularly for children in a complex humanitarian emergency entailed by a civil war. Therefore, special caution must be taken in generalizing the results of this study. Further research is needed to better assess the needs of the affected population.

However, it is obvious that for children as a vulnerable population, a protracted civil war results in displacement, loss of family members, lack of education, and deficient health care provision. These threats make children even more at risk for abuse, exploitation, malnutrition, and communicable diseases, leading to increased morbidity and mortality.

\section{About the Authors}

Department of Emergency Medicine, Hamad Medical Corporation, Doha, Qatar (Dr Elsafti), Faculty of Arab Diploma of Disaster Medicine, Arab Institute of Continuing Professional Development, Arab Medical Union, Cairo, Egypt (Drs Elsafti and Redwan), Department of Emergency Medicine, Universitair Ziekenhuis Brussel, and Research Group on Emergency and Disaster Medicine, Vrije Universiteit Brussel, Brussels, Belgium (Drs van Berlaer, Debacker, and Hubloue), Qatar Red Crescent, Turkey Mission, Gaziantep, Turkey (Dr Al Safadi), Department of Public Health, Biostatistics and Medical Informatics Research Group, Vrije Universiteit Brussel, Brussels, Belgium (Dr Buyl), Department of Anesthesia and Critical Care, Faculty of Medicine, Zagazig University, Zagazig, Egypt (Dr Redwan).

Correspondence and reprint requests to Gerlant van Berlaer, MD, Eeuwlaan 40 -BE 1850 Grimbergen, Belgium (e-mail: gerlant.vanberlaer@uzbrussel.be).

\section{Acknowledgments}

This research received no specific grant from any funding agency in the public, commercial, or not-for-profit sectors. Drs Eslafti and van Berlaer contributed equally to this paper.

Data repository: DRYAD: doi:10.5061/dryad.73ff4

\section{Supplementary material}

To view supplementary material for this article, please visit http://dx.doi.org/10.1017/dmp.2016.165

Published online: October 14, 2016

\section{REFERENCES}

1. Guha-Sapir D, Rodriguez-Llanes J, Hicks M, et al. Civilian deaths from weapons used in the Syrian conflict. BMJ. 2015;351:h4736. doi: 10.1136/ bmj.h4736.

2. United Nations Office for the Coordination of Humanitarian Affairs (OCHA). Syrian Arab Republic. Syria Crisis: Regional Overview. About the Crisis. OCHA Website http://www.unocha.org/syrian-arab-republic/ syria-country-profile/about-crisis. Accessed September 4, 2016.

3. Human Rights Watch. World Report 2016: Syria country summary. https://www.hrw.org/sites/default/files/syria.pdf. Published January 2016. Accessed September 4, 2016. 
4. Çelikel A, Karbeyaz K, Kararslan B, et al. Childhood casualties during civil war: Syrian experience. J Forensic Leg Med. 2015;34:1-4. doi: 10.1016/j.jflm.2015.04.021.

5. Devi S. Syria's health crisis: 5 years on. Lancet. 2016;387:1042-1043.

6. Doocy S, Lyles E, Delbiso T, Robinson C, IOCC/GOPA Study Team. Internal displacement and the Syrian crisis: an analysis of trends from 2011-2014. Confl Health. 2015;9:33. doi: 10.1186/s13031-015-0060-7.

7. Sen K, Al-Faisal W, AlSaleh Y. Syria: effects of conflict and sanctions on public health. J Public Health (Oxf). 2013;35:195-199. doi: 10.1093/ pubmed/fds090.

8. Ben Taleb Z, Bahelah R, Fouad F, et al. Syria: health in a country undergoing tragic transition. Int J Public Health. 2015;60:S63-S72. doi: 10.1007/s00038-014-0586-2.

9. Baron-Lee J, Bonner B, Knapp C, et al. Factors associated with having a medical home for children at-risk of experiencing negative events: results from a national study. Matern Child Health J. 2015;19:2233-2242.

10. Robert Graham Center for Policy Studies in Family Medicine and Primary Care. The patient centered medical home: history, seven core features, evidence and transformational change. Graham Center Washington, 2007. http://www.graham-center.org/dam/rgc/documents/ publications-reports/monographs-books/rgcmo-medical-home.pdf. Published November 2007. Accessed September 4, 2016.

11. United Nations. Joint Humanitarian Statement on Syria 5 years. http://www.un.org/News/dh/infocus/Syria/Joint\%20Humanitarian\% 20Statement\%20on\%20Syria_En.pdf. Accessed September 4, 2016.

12. Touma J, WHO, UNICEF. Children of Syria Report 2016: No place for children. Amman, Jordan, UNICEF Knowledge Centre 2016. http:/ childrenofsyria.info/wp-content/uploads/2016/03/SYRIA5Y-REPORT-12MARCH.pdf. Published March 14, 2016. Accessed September 4, 2016.

13. Devakumar D, Birch M, Rubenstein L, et al. Child health in Syria: recognising the lasting effects of warfare on health. Confl Health. 2015;9:34. doi: 10.1186/s13031-015-0061-6.

14. Bilukha O, Jayasekaran D, Burton A, et al. Nutritional status of women and child refugees from Syria-Jordan, April-May 2014. MMWR Morb Mortal Wkly Rep. 2014;63:638-639.

15. Sharara S, Kanj S. War and infectious diseases: challenges of the Syrian civil war. PLoS Pathog. 2014;10:e1004438. doi: 10.1371/journal. ppat.1004438.

16. Becker T, Bartels S, Hansoti B, et al; Global Emergency Medicine Literature Review (GEMLR) Group. Global emergency medicine: a review of the literature from 2014. Acad Emerg Med. 2015;22:976-984. doi: 10.1111/acem.12733.

17. Qatar Red Crescent Society. QRC Supervises 8th Polio Vaccination Campaign for 768,254 Children in Syria. http://reliefweb.int/report/ syrian-arab-republic/qrc-supervises-8th-polio-vaccination-campaign-768254children-syria. Published March 23, 2015. Accessed September 4, 2016.
18. Doocy S, Sirois A, Anderson J, et al. Food security and humanitarian assistance among displaced Iraqi populations in Jordan and Syria. Soc Sci Med. 2011;72:273-282. doi: 10.1016/j.socscimed.2010.10.023.

19. UNICEF. Refugee and migrant crisis in Europe (September 2015). http://www.unicef.org/publicpartnerships/files/Refugee_and_migrant_ children_in_Europe__Sept_2015.pdf. Accessed September 4, 2016.

20. Sirin S, Rogers-Sirin L. The educational and mental health needs of Syrian refugee children. In: Capps R, Hopper K, eds. Young Children in Refugee Families. Washington, DC: Migration Policy Institute; 2015. http://www.migrationpolicy.org/sites/default/files/publications/FCD-SirinRogers-FINAL.pdf. Accessed September 4, 2016.

21. Catani C, Jacob N, Schauer E, et al. Family violence, war, and natural disasters: a study of the effect of extreme stress on children's mental health in Sri Lanka. BMC Psychiatry. 2008;8:33.

22. Dirkzwager A, Kerssens J, Yzermans C. Health problems in children and adolescents before and after a man-made disaster. J Am Acad Child Adolesc Psychiatry. 2006;45:94-103.

23. Syrian Ministry of Health; Nutrition Research Institute. Rapid Nutritional Assessment for Children (6-59) Months of Age in Syrian Refuge Families in Al-Anbar Governorate/Al Qa'im District. http://data.unhcr. org/syrianrefugees/download.php?id=1838. Published 2013. Accessed September 4, 2016.

24. United Nations Office for the Coordination of Humanitarian Affairs (OCHA). Revised Syria Humanitarian Assistance Response Plan (SHARP), Syrian Arab Republic, January-December 2013. OCHA Website. http://www.unocha.org/cap/appeals/revised-syria-humanitarianassistance-response-plan-sharp-january-december-2013 . Published June 7, 2013. Accessed September 4, 2016.

25. Al-Akour N, Khassawneh M, Khader Y, et al. Factors affecting intention to breastfeed among Syrian and Jordanian mothers: a comparative cross-sectional study. Int Breastfeed J. 2010;5:6. doi:10.1186/17464358-5-6.

26. International Federation of Red Cross and Red Crescent Societies. Qatar Red Crescent annual report 2014. Doha, Qatar 2014. http://www.ifrc. org/Global/Documents/Secretariat/201601/1296700-IFRC\%20Annual\% 20Report\%202014-EN_LR.pdf. Accessed September 4, 2016.

27. Noji E. Public health in the aftermath of disasters. BMJ. 2005;330:1379-1381.

28. Cousins S. Contaminated vaccine deaths a serious setback for Syria. Lancet. 2014;384:1172.

29. Roberts L. A war within a war. Fighting a major polio outbreak in the midst of Syria's bitter civil war is a test of commitment-and diplomacy. Science. 2014;343:1302-1305. doi: 10.1126/science.343.6177.1302.

30. Jones G, Haeghebaert S, Merlin B, et al. Measles outbreak in a refugee settlement in Calais, France: January to February 2016. Euro Surveill. 2016;21: pii $=30167$. doi: http://dx.doi.org/10.2807/1560-7917.ES.2016. 21.11.30167. 